\title{
CREATION AND EVALUATION CYCLE OF A DISTANCE MODULE FOR NURSING UNDERGRADUATES, NAMED "MEDICATION ADMNISTRATION"1
}

\author{
Paulo Celso Prado Telles Filho ${ }^{2}$
}

Silvia Helena De Bortoli Cassiani ${ }^{3}$

Telles Filho PCP, Cassiani SHB. Creation and evaluation cycle of a distance module for nursing undergraduates, named "medication admnistration". Rev Latino-am Enfermagem 2008 janeiro-fevereiro; 16(1):78-85.

The objective of this study was to describe the creation cycle of the module "medication administration" and to evaluate it. It is an evaluation research, using the Engagement Theory as a methodological/theoretical approach carried out in two phases: the first related to the creation of the module and the second to its evaluation by specialists using the instrument based on the Model of Analytical Appreciation of Hypermedia Systems. The creation cycle of the module followed the following steps: gathering the objectives of the module, organization of the content, selection of the media, creation of the classes and activation of the learning process. It was evaluated by contents specialists, informatics specialists and nursing students. The evaluation of the distribution and the accessibility of the contents, the utilization of images, the clarity and ease of execution of the program were positive. The module was considered appropriate to be used with nursing students.

DESCRIPTORS: education, distance; nursing; pharmaceutical preparations

\section{CICLO DE CREACIÓN Y EVALUACIÓN DE UN MÓDULO A DISTANCIA, PARA ESTUDIANTES DE ENFERMERÍA, TITULADO "ADMINISTRACIÓN DE MEDICAMENTOS"}

Este estudio tuvo como objetivo describir el ciclo de creación de la disciplina "Administración de Medicamentos" y realizar su evaluación. Fue una investigación de evaluación, que utilizó la Teoría del Comprometimiento como referencia teórica metodológica, la que fue realizada en dos fases: la primera está relacionada a la creación del módulo y la segunda, a la evaluación por especialistas a través del instrumento basado en el Modelo de Apreciación Analítica de Sistemas Hipermedia. La descripción del ciclo de creación del módulo siguió las siguientes etapas: levantamiento de los objetivos del módulo, organización del contenido, selección de los medios de comunicación, creación de las clases y organización y ejecución del aprendizaje. El ciclo de creación analizado por especialistas en contenido en informática y por estudiantes de enfermería, evaluaron positivamente la distribución y accesibilidad del contenido, a la utilización de imágenes, a la claridad y a la facilidad de ejecución del programa. El módulo fue considerado apropiado para ser utilizado por los alumnos del curso de enfermería.

DESCRIPTORES: educación a distancia; enfermería; preparaciones farmacéuticas

\section{CICLO DE CRIAÇÃO E AVALIAÇÃO DO MÓDULO ADMINISTRAÇÃO DE MEDICAMENTOS PARA ENSINO À DISTÂNCIA}

Este estudo teve por objetivos descrever o ciclo de criação do módulo Administração de Medicamentos, bem como proceder à sua avaliação. Trata-se de pesquisa de avaliação, que utilizou a Teoria do Engajamento como referencial teórico-metodológico, realizada em duas fases: a primeira, relacionada à criação do módulo e a segunda, à avaliação por especialistas, através do instrumento baseado no Modelo de Apreciação Analítica de Sistemas Hipermídia. A descrição do ciclo de criação do módulo seguiu os seguintes passos: levantamento dos objetivos do módulo, organização do conteúdo, seleção da mídia, criação das aulas e operacionalização da aprendizagem. Foi avaliado por especialistas em conteúdo, em informática e por graduandos de enfermagem, os quais o avaliaram positivamente em relação à distribuição e acessibilidade de conteúdo, à utilização de imagens, à clareza e à facilidade de execução do programa. O módulo foi, pois, considerado apropriado para utilização com alunos do curso de enfermagem.

DESCRITORES: educação a distância; enfermagem; preparações farmacêuticas

\footnotetext{
${ }^{1}$ Paper extracted from Doctoral Dissertation; ${ }^{2}$ RN, Doctoral student, Faculty, Federal University of Vales do Jequitinhonha e Mucuri, Brasil, e-mail: ppradotelles@yahoo.com.br; ${ }^{3}$ Advisor, Full Professor, e-mail: shbcassi@eerp.usp.br. University of São Paulo at Ribeirão Preto College of Nursing, WHO Collaborating Centre for Nursing Research Development, Brazil.
} 


\section{INTRODUCTION}

The contemporary society demands individuals to develop their abilities of raising theories, reflecting, analyzing and organizing, which validate conscious decision making. It is necessary to develop talents that allow for autonomous ways of creation, communication and expression, generating attitudes of cooperation and reciprocity.

In this perspective, distance education stands out as an educative process in which learning occurs through a physical separation between the students and the teachers. Communication and learning take place through technological resources that go beyond oral exposition.

In this kind of process, both the student who will use it, and the teacher who develops the material need to be capable. Both these parties' motivation for learning is the accelerated scientific and technological development of the current world, which brings about constant changes in work places, demanding professionals able to adapt themselves to the changes and who are equipped and motivated for continuous learning.

A study cited in this research focused on the learning environment, with the use of the Internet, addressing intravenous therapy teaching. It aimed at developing educational material on this therapy, using the Internet and evaluating its use by the students. The latter positively evaluated the learning opportunity through the Internet, mentioning the interaction with the instructor, space-time flexibility, access to technical resources and aspects related to course content organization ${ }^{(2)}$.

Therefore, based on the idea that distance education resources are very useful, efforts were made to conduct and use it in the nursing area.

A study that revealed the educational needs of hospital nurses in terms of medication administration exposed the need for knowledge on contents like: action mechanisms, medication preparation and administration, medication interactions, stability, adverse effects of the medication and other aspects ${ }^{(3)}$.

This data indicated the existence of knowledge deficits on essential questions for safe and correct medication administration.

In view of these considerations and aware of the challenge of extending knowledge on medication administration, the researcher aimed to carry out a study that would present the contribution related to the subject: teaching medication administration, using distance education as a possibility of development in professional education of nursing undergraduates.

Therefore, the development of this study was proposed, which intended to describe the creation cycle of a distance module called "Medication Administration", as well as to evaluate it for its later implementation in undergraduate Nursing courses.

\section{OBJECTIVES}

This article aimed at:

- Describing the creation cycle of a distance module in the Teleduc environment, called "Medication Administration".

- Proceeding to the evaluation of the module mentioned by specialists in content, informatics and undergraduates in nursing, through an instrument based on the Analytical Appreciation Model of Hypermedia Systems.

\section{METHODOLOGY}

First Phase

The first phase of the work is an evaluation research, aimed at discovering how well a practice or program is working out when used to search for answers to practical questions ${ }^{(4)}$.

In nursing education, there is usually a need to evaluate the range of goals and the efficiency of the means used to achieve a goal ${ }^{(4)}$. This study aimed at describing the development and evaluation of a module in a virtual learning environment, through information and communication technologies available on the web.

The engagement theory developed by Greg Kearsley, a consultant specialized in on-line and distance education, Assistant Professor of the Distance Education Program at the University of Maryland USA, was used as a theoretical/methodological reference framework.

The option to use the latter is justified because the intention was to develop a distance module for medication administration teaching which would reflect the current and innovative learning focus that unites individuals with common interests and seeks collaboration and connectivity. 
The main characteristics of this theory are related to collaboration (students working together); connectivity (all students connected to each other all of the time); community (groups are defined according to common interests) and multisensoriality (the information can involve sound, graphs and figures) ${ }^{(5)}$

Therefore, its fundamental idea is the interaction among students engaged in learning activities. Such theory differs from others because it promotes human interaction in the context of group activities and not in the individual's interaction with the instructional program only ${ }^{(6)}$.

Important determinants that stand out in the quality of the instructional material are: little quantity of information on each screen and the use of different styles, font sizes and colors to highlight ideas, using figures to transmit them ${ }^{(7)}$.

The below figure presents the module development cycle.

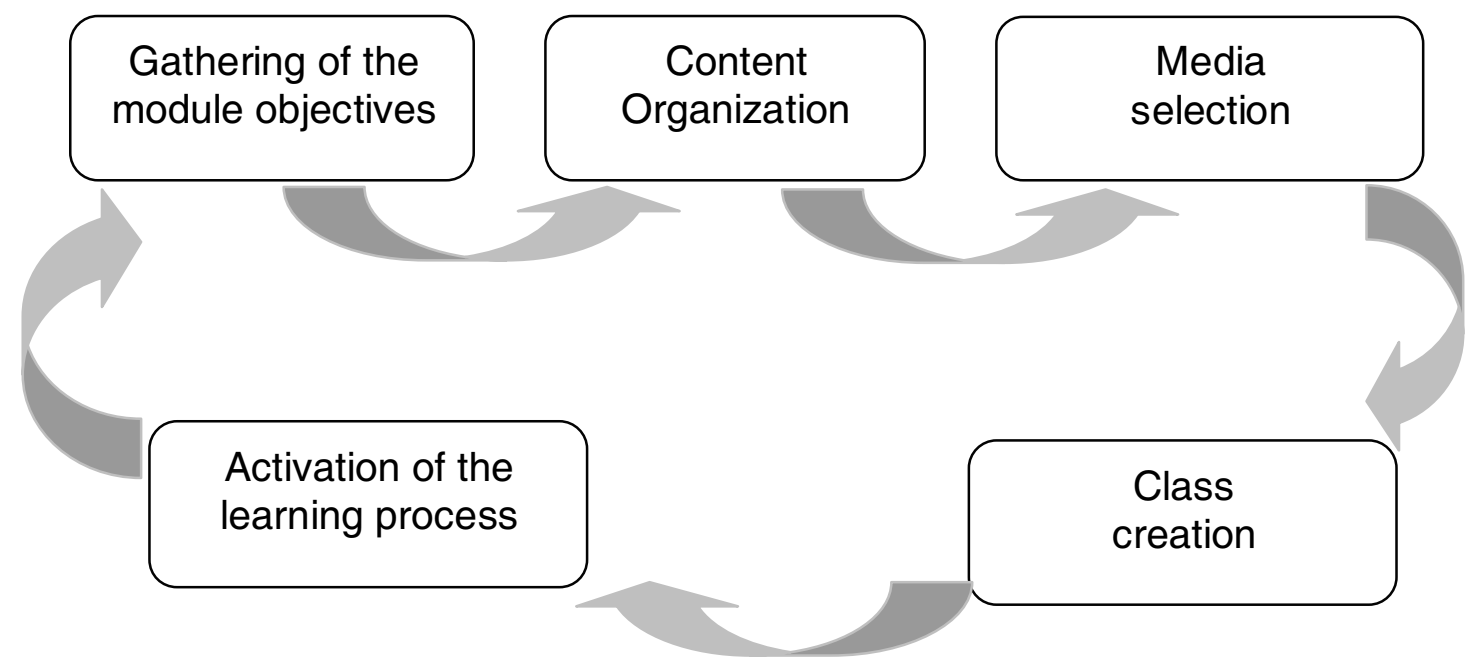

Figure 1 - Development cycle of the module: "Medication Administration"

Second Phase

Study and Population Location - Target

The module evaluation was developed at a university in the interior of São Paulo, Brazil.

It was carried out by ten specialists: five specialists in content were nurses, post-graduates and university professors. It is worth stressing that all of them attended the criteria of having a Master's Degree and being professors in Nursing Fundamentals. There were five specialists in informatics: a system analyst, an electronic engineer, an undergraduate in Systems Analysis and two informatics technicians. All of them attended the criteria of being involved with informatics and teaching technology, as well as with educational computer programs.

Posters were hung up in the research institution, describing the study goals and asking interested people to contact the researcher. Five students from the eighth term showed up and were interested in participating.

\section{Evaluation Instrument}

The evaluation was performed through an instrument based on the Analytical Appreciation Model of Hypermedia Systems ${ }^{(8)}$, which was adapted and validated $^{(9)}$ to evaluate educational software.

\section{Ethical Aspects}

The study was authorized by the General Board of the research institution. It started after the approval by the Research Ethics Committee at the University of São Paulo College of Nursing, registered under number 0304/2002. Each participant was aware of the Free and Informed Consent Term for Participation in Research and issued a written record with the approval to participate in the research. 


\section{RESULTS AND DISCUSSION}

First Phase

The steps of the development cycle of the "Medication Administration" module are described below.

Gathering the objectives of the module

The objectives were raised based on the program content of the subject "Fundamentals for the Care Process II", taught at the institution where the researcher was a professor; on his experience in courses about the theme, taught to undergraduates and postgraduates in the health area in general and in nursing in particular; on his participation in scientific events where the theme has been discussed with specialists in the area.

The objectives of the module are presented as follows.

- General Objective

Develop competences related to several contents about medication administration and to the execution of its techniques, to motivate students for the development.

\section{- Specific Objective}

Class 1: develop competences related to pharmacological aspects, nursing orientations and information sources for safe medication administration. Class 2: develop competences related to the preparation of the material for medication administration.

Class 3: develop competences related to intradermal medication administration.

Class 4: develop competences related to subcutaneous medication administration.

Class 5: develop competences related to intramuscular medication administration.

Class 6: develop competences related to endovenous medications administration.

\section{Content organization}

After the module objectives were determined, the content was organized. Therefore, all material was joined to be organized in a logical sequence for its broad and clear presentation.
Scientific articles, several materials prepared as content for the classes, materials presented in scientific events and books were part of this material. The content was organized as presented in Table 1.

Table 1 - Content distribution of the "Medication Administration" module according to classes and topics. Descalvado, 2005

\begin{tabular}{|c|c|}
\hline Classes & Topics \\
\hline $\begin{array}{l}1 \text {-Pharmacological aspects } \\
\text { nursing orientation and } \\
\text { information sources for safe } \\
\text { medication administration }\end{array}$ & $\begin{array}{l}\text { - Organic reactions to the use of medication } \\
\text { - Factors that change the action of the medication } \\
\text { - Interaction, adverse and toxicant reaction of the } \\
\text { medication }\end{array}$ \\
\hline & $\begin{array}{l}\text { - Medication administration during pregnancy and } \\
\text { lactation } \\
\text { - The educative role of the nurse in medication } \\
\text { administration } \\
\text { - The nursing process in medication administration } \\
\text { - Sources of information on medication }\end{array}$ \\
\hline $\begin{array}{l}2 \text {-Preparation of the } \\
\text { material for injectable } \\
\text { medication administration }\end{array}$ & $\begin{array}{l}\text { - Basic precautions } \\
\text { - Hand washing } \\
\text { - Injection preparation and administration } \\
\text { - Suction of the medication from a bottle } \\
\text { - Suction of the medication from an ampoule } \\
\text { - Association of medication in The syringe }\end{array}$ \\
\hline $\begin{array}{l}3 \text {-Intradermal Medication } \\
\text { Administration }\end{array}$ & $\begin{array}{l}\text { - Application places } \\
\text { - Steps for the technique application } \\
\text { - Technique application }\end{array}$ \\
\hline $\begin{array}{l}4 \text {-Subcutaneous Medicatior } \\
\text { Administration }\end{array}$ & $\begin{array}{l}\text { - Location of the application areas } \\
\text { - Steps for the technique application } \\
\text { - Medication administration } \\
\text { - Heparin administration } \\
\text { - Insulin administration }\end{array}$ \\
\hline $\begin{array}{l}5 \text {-Intramuscular Medication } \\
\text { Administration }\end{array}$ & $\begin{array}{l}\text { - Location of the muscle areas } \\
\text { - Dorsogluteal area } \\
\text { - Ventrogluteal area } \\
\text { - Vast lateral area } \\
\text { - Deltoid area } \\
\text { - Medication administration } \\
\text { - Administration of the application technique in Z }\end{array}$ \\
\hline $\begin{array}{l}6 \text {-Endovenous Medication } \\
\text { Administration }\end{array}$ & $\begin{array}{l}\text { - Indication } \\
\text { - Vein selection } \\
\text { - Preparation of the solution and application area } \\
\text { - Bottle inspection } \\
\text { - Infusion set preparation } \\
\text { - Insertion of a peripherical vascular access device } \\
\text { - Vein dilation } \\
\text { - Insertion of a scalp access device } \\
\text { - Fixation of the venous access device } \\
\text { - Insertion and fixation of a malleable plastic catheter } \\
\text { - Immobilization of the end } \\
\text { - Use of a splint }\end{array}$ \\
\hline
\end{tabular}

A fact that stands out is that each class mentioned above has specific exercises and that the 
entire content in this table was compiled into a text, presented in 102 pages, typed and reviewed using the text editor Word.

It also stands out that this content went through a language adaptation process, in order to become appropriate for the interactive communication means of the Internet. For this purpose, some points were observed, such as the recommendation that the style should be simple and used in the habitual sense, that the images should be subtitled, the paragraphs should be short and that competent sources of quotation and reference should be used, as well as the fact that hyperlinks at the end of each screen should be stimulated and the quantity of text should be reduced, but not of information $^{(10)}$.

Media selection

After determining the objectives and organizing the content, the media selection proceeded, which is a crucial moment for the professor, because it is the time to decide on the best way to present the content to the students ${ }^{(11)}$.

After the long bibliographic material reading, the discussion with postgraduate colleagues, pedagogues and systems analysts, the whole content was made available in the Teleduc environment.
Teleduc was considered a support environment for the distance education on the web that has been developed since 1997 by the Center of Informatics Applied to Education - NIED, in partnership with the Institute for Computer Sciences Institute IC, both from the State University of Campinas (UNICAMP). This environment was developed in a continuous and participative way, having all of its tools idealized and projected according to the needs related by its users ${ }^{(12)}$.

The architecture of this platform was developed based on the activities. Several tools were arranged for the student, such as support and reading material and frequent questions. These tools promote both teacher-student and student-student interaction and, consequently, collective work.

Creation of classes

The creation of classes followed the determination of the module objectives, as well as the content organization and media selection, which were already presented.

A fact that stands out is that 120 photographs were taken, especially produced for the module. After the association of the objectives, contents and possibilities established for the media, the classes were creation as shown in the following conceptual maps.

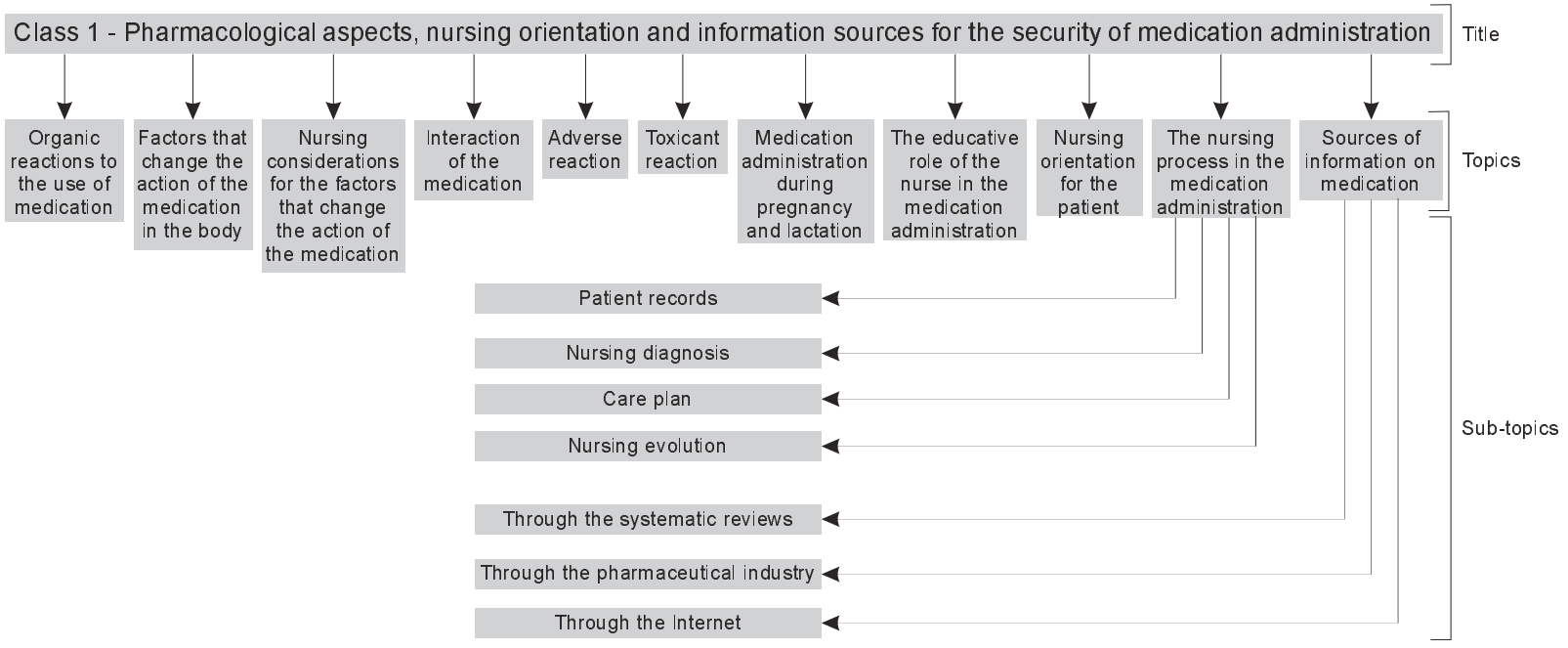

Exercises Reference Lis

Figure 2 - Conceptual mapping of class 1 


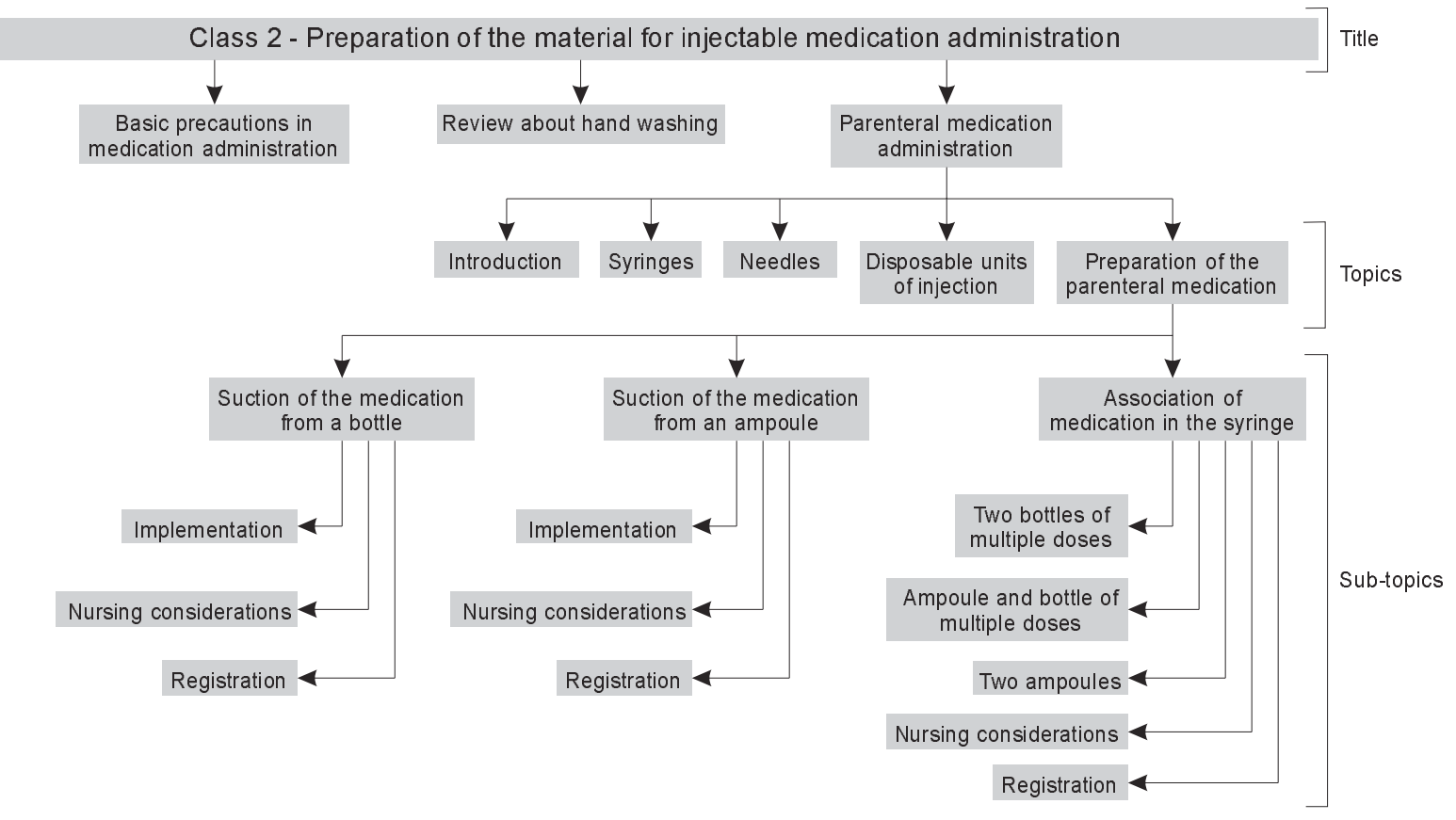

Exercises Reference List

Figure 3 - Conceptual mapping of class 2

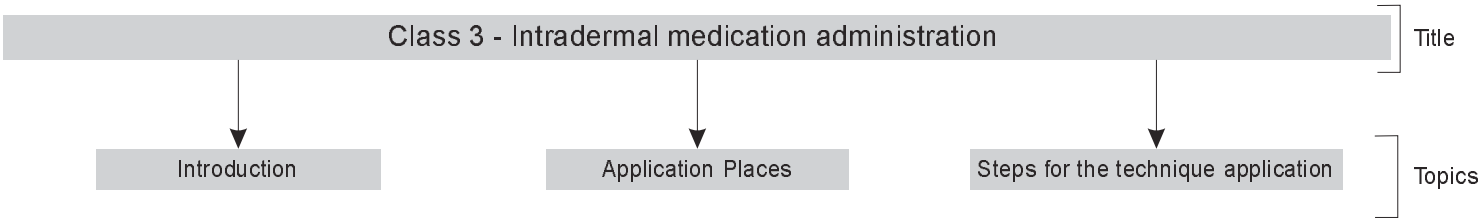

Exercises Reference List

Figure 4 - Conceptual mapping of class 3

It is important to stress that the classes related to subcutaneous, intramuscular and endovenous medication administration followed conceptual mappings similar to the class on intradermal administration.

\section{Activation of the learning process}

The module has a total schedule of 50 hours, considering the hours of meetings at school (13 hours and 20 minutes), classes in the Teleduc environment (20 hours), as well as classes in the laboratory (16 hours and 40 minutes).

The four meetings aim to provide information on specific needs during the module implementation. This way, in the first meeting, students are offered general orientations about the module development, explaining and demonstrating its use, which approximates the students, the instructor and the online Teleduc environment. The second and third meetings are held after the conclusion of classes 3 and 6 , because it is believed that, in this period, content revisions are necessary, in which possible questions related to the corresponding contents are answered. In the fourth meeting, the theoretical evaluation is made.

What the distance content is concerned, there is the screen "Welcome", presenting the necessary information to learn how to use the Teleduc platform, essential for the process. In order to continue the user experience, it is necessary that the participant uses the tool "course dynamic", through which the students get information on class dates and schedules, contents, exercises, chats, forums, laboratory classes and evaluations scheduled during the module. 
It is important to highlight that the dynamic of the module comprises the following sequence of activities: classes, exercises, chats and forum discussions. On these screens, the dates scheduled for this sequence are specified; it is important to stress that the classes are available during the entire period of the module development and that the exercises, chats and forums discussions are available for a week from the publication of the content of the classes it refers to.

In order to access the content of the class itself, the tool "readings" should be used.

The opening screen of the classes of the module allows the students to surf in a non linear way, in other words, according to their study needs. The student can access the content from classes one to six, the support material, the image links and list of references.

After studying the content regarding the class, the exercises are done and the program provides the student a grade immediately after its conclusion.

The next steps are the use of the chat session and the discussion forum, which the students use to exchange information on the content studied, as well as to clarify questions; the professor can then visualize the students' access and register them for later analysis.

The laboratories, from one to five, refer to practical classes, in other words, to technique training and practical evaluation. Laboratory 1 deals with the preparation of the material for injectable intradermal medication; laboratory 2, subcutaneous; laboratory 3, intramuscular; laboratory 4, endovenous and laboratory 5, practical evaluation.

In order to follow-up the students' development, formative evaluation is used, verifying and quantifying, in short periods of time and with tools from Teleduc, the accesses to the following items: content of each class, exercise access and resolution, access to the chat and discussion forum.

The additive evaluation takes place at the end of the module, through two classroom evaluations: a theoretical and a practical one, both using printed material, according to the guidelines of the educational institution where the module is implemented.

Second Phase

The results of evaluations by specialists in content refer to the content distribution and accessibility, the explicitness of its presentation, the structure and accuracy of the information presented, the utilization of images and its relation to the text information, the presentation of diverse texts that correspond to the objectives of the module and the relevance of the exercises to reinforce the content.

The unanimous agreement of the specialists in content regarding all items above cited and evaluated was observed, as all of the five participants checked the item "In Conformity" of the instrument used.

Positive aspects emerged from these observations, mostly in what concerns the photographs in a process of detriment of images; the placement of tests at the end of each class; the existence of personal meetings during the module, as a way to clarify possible questions; the information quality and its contribution to daily nursing practice; content explicitness and quantity, the tests put at the end of each class as a possibility of revision and fixation of the knowledge acquired and the instructional sequence of the classes as learning motivators.

Continuing with the evaluation by specialists, there is the evaluation by the specialists in informatics.

The items evaluated by these specialists were reported regarding their explicitness and the visualization of the main menu presentation, logical and pleasant sequence of the classes, suitability of the visual presentation for the study objective, easy execution of the program, speed of access, accessibility of the contents, efficient use of platform resources and easy interaction and communication provided by the environment. Regarding the items mentioned, $100 \%$ of conformity was registered.

As to the observations, information regarding the quality of the education system and easy accessibility were described. However, an item was pointed out as requiring modification regarding the item readings, as the quantity of bibliographical references should be increased.

After the modification was carried out, there was the evaluation by undergraduates from a nursing course, described next.

The same items evaluated by the specialists in informatics and content were evaluated by five undergraduates and, according to the records, 12 items received the classification "In Conformity". Three participants disagreed with the items "The main menu presentation is clear and of easy visualization" and "The access is fast". 
Some positive aspects emerged in the observations, such as the relation of the module to the digital evolution and professional development, the placement of the content in a clear way and the use of the module for students and people outside the health area.

Regarding aspects requiring modification, the delay in access time stood out. It should be explained that this depends on the net the student is accessing the program from, as each network has a different configuration that interferes with the speed.

After all modifications were completed, it is believed that the module is appropriate to be implemented in undergraduate nursing courses.

\section{FINAL CONSIDERATIONS}

This study described the creation cycle of the "Medication Administration" module, developed in the educational environment Teleduc, based on up-to-date bibliography. For this purpose, Engagement Theory was used, which seeks the union of individuals with common interests, collaboration and connectivity.

\section{REFERENCES}

1. Magdalena BC, Costa IT. Internet na sala de aula: com a palavra os professores. Porto Alegre: Artmed; 2003.

2. Dias D.C, Cassiani SHB. Educação sem distâncias: utilização do Web CT como ferramenta de apoio para o ensino de terapia intravenosa na graduação de enfermagem. Rev Brasileira de Enfermagem 2003; 56(4):443-6.

3. Telles PCP Filho, Cassiani SHB. Administração de medicamentos: aquisição de conhecimentos e habilidades requeridas por um grupo de enfermeiros. Rev LatinoAmericana de Enfermagem 2004; 12(3):533-40.

4. Polit D, Hungler BP. Nursing research - principles and methods. 6a ed. Philadelphia: Lippicontt; 1999.

5. Kearsley G. New Developments in Learning. [citado em 2004 jul 7]. Disponível em: http://home.sprynet.com/ $\sim$ gkearsley/.htm.

6. Kearsley G. O profesor virtual: um estudo de caso pessoal. [citado em 2003 dez 23] Disponível em: http:// home.sprynet.com/ gkearsley/.htm.

7. Kearsley G. Training for tomorrow. Distributed learning through computer and communications technology. New York: Addison-Wesley Publishing; 1985.

8. Struchiner M. Introdução a informática na área da saúde. Rio de Janeiro: NUTES/UFRJ; 1997
The following sequence was adopted for the description: determining the objectives of the module, content organization, media selection, creation of classes and activation of the learning process.

The "Medication Administration" module was created in the Teleduc environment, based on up-to-date bibliography and with practical examples. It is a resource integrated to the pedagogical process as one of its mediators, providing the participants with knowledge construction on medication administration, to be built in constant interaction between students and teacher.

It was positively evaluated by specialists in content, informatics and undergraduates in nursing in terms of content distribution and accessibility, explicitness of its presentation, information structure and accuracy, image utilization and its relation to the text information, presentation of diverse texts, relevance of the exercises for content reinforcement, explicitness and visualization of main menu presentation, logical and pleasant sequence of the classes, suitability of visual presentation, easy execution of the program and interaction and communication provided by the environment. The module was then considered appropriate for use with nursing undergraduates.

9. Lopes MVO, Araújo TL, Silva RM. Software para o auxílio a prática docente no ensino de necessidades humanas básicas. Texto \& Contexto - Enfermagem. 2000; 9(1):79-92.

10. Kearsley G, Moore M. Distance education: a system view. Belmont (USA): Wasdsworth Publishing; 1996.

11. Zaína LAM. Acompanhamento do aprendizado do aluno em curso a distância através da Web: metodologias e ferramentas [dissertação]. São Paulo (SP): Escola Politécnica/USP; 2002.

12. Rocha HV. O ambiente Teleduc para educação a distância baseada na Web: princípios, funcionalidades e perspectivas de desenvolvimento. Campinas (SP): Unicamp; 2000. 